\title{
Digital Activism in Asia: Good, Bad, and Banal Politics Online
}

\author{
Bart Barendregt \\ Leiden Institute of Cultural Anthropology and Sociology, Leiden, \\ the Netherlands \\ barendregt@fsw.leidenuniv.nl \\ Florian Schneider \\ Leiden University Institute for Area Studies, Leiden, the Netherlands \\ f.a.schneider@hum.leidenuniv.nl
}

\begin{abstract}
This article introduces the special issue on 'Digital Activism' by exploring some of the trends in social media activism and scholarship thereof. The authors ask to what extent this literature helps us understand Asian forms of online activism, which forms of activism have relatively done well, and whether Asian activism requires its own theorizing. Most of all, it is a plea for a careful and ethnographically informed approach to digital activism. Although outwardly they look similar and use the same templates, manuals, or even similar media strategies, not all forms of online activism promote democratic values. Furthermore, we argue that much of what happens under the banner of digital activism is not necessarily politics with a capital $\mathrm{P}$ but, rather, consists of everyday forms of engagement, with sometimes seemingly vulgar contents and often familiar routines and natural forms, yet in their impact such 'banal activism' may have political implications.
\end{abstract}

\section{Keywords}

Asia - civic engagement - digital activism - mediatization - online community social media 
New media have always held not just the promise of compressing space/time but also, and inherently, of spreading the values of transparency and democracy and of serving as a potential means of better and just governance. In his Victorian Internet, Standage (1998) gives a fine example of this deep faith in technology when he details that, in the early 185 os, submarine telegraph cables started to connect not only countries and continents but the whole world; people and places soon seemed able 'to catch up', primitive societies would be 'upgraded', corruption would cease, and cultural, social, and political divides would become relics. The telegraph, it was believed, was made for instantaneous communication without intermediaries; everyone could and would be heard by those in control, and, as a consequence, we could all be in control.

By no means was this techno-optimistic sentiment restricted to the Western hemisphere. Rafael (2003: 400) reports on similar expectations and 'fantasies of direct communication' in the aftermath of introducing telephony to the Philippines in the nineteenth century. He refers to an 1889 satirical piece written by its national hero, the novelist Jose Rizal, titled 'Por Telefono', which 'situates the narrator as an eavesdropper. He listens intently to the sounds and voices that travel between the Spanish friars in Manila-regarded as the real power in the colony - and their superiors in Madrid' (Rafael 2003: 400). Rizal, he argues, thus 'wiretaps his way, as it were, into the walls of the clerical residence, exposing their hypocrisy and excesses', concluding that telephony, like print and other types of telecommunication technology, reveals 'what was once hidden, to repeat what was meant to be secret, and to pass on messages intended for a particular circle' (Rafael 2003: 401). New media come with new affordances and new modes and launch new actors, enabling, for example, activists with new platforms and abilities to express themselves politically. And, as history recounts, the meek and the marginal initially seem to benefit most from this potential, but the powers that be are likely to catch up quickly.

Fast forward to the early 2020s. Access to an increasingly broad range of social media platforms, political, financial, and other subsequent crises, and a widely felt disenchantment with traditional politics in generations $\mathrm{X}$ to $\mathrm{Z}$, have fed the urge for new forms of networked activism. We have seen the rise (and often already decline) of the voting-booth selfie, political hackers, and techpol nerds. We have witnessed what networked citizens and the sheer outrage of the much-evoked 99\% can do, in both 'tweets and the streets' (Gerbaudo 2012). And many are the stories of networked engagement, from concerted DDoS (distributed denial of service) attacks on authoritarian regimes to the hashtag activism of \#Illridewithyou, \#JeSuisCharlie, \#Pray4, and \#Metoo. The 
internet and (all sorts and flavours of) political activism have proven to be a golden combination, and although 'roots, routes, and routers' are multifaceted, certain trends and mechanisms have become clearly discernible (Lim 2018).

Some of these activist causes are progressive, and others are right-wing populist (Nagle 2017) or outright authoritarian (Hopkins 2014). But virtually no campaign lacks an online presence, and no political pamphlet fails to be uploaded to the web. As a consequence, digital activism has been among the most studied and discussed arenas in which the digitization of society is taking place. In recent years, this literature has also started to cover digital activism in Asia, highlighting online engagement for, by, and with Asians (see e.g. Shah et al. 2015; Zhang \& Lallana 2013; on instances of Asian 'artivism', see Hudson \& Barendregt 2018). Nonetheless, much of the literature, unsurprisingly, focuses on the West and how the internet and, more recently, social media activism have helped change the face of conventional politics there, from a top-down and state perspective as well as from a bottom-up perspective, describing political players resorting to alternative digital tactics.

Much of the early literature on digital politics and activism has been driven by sociologically informed concepts, such as Habermas's (1991) Öffentlichkeit (i.e. public), and many of them applied his idea of the bourgeois salon in analyzing seemingly similar 'coffeehouses' that have emerged online. Such simple borrowing has been criticized by, for example, Papacharissi (2008) and even Habermas himself, rightly pointing out that today's online salons can just as easily become 'digital gated communities', leaving great space for hasty opinions, hoaxes, or hate speech, but far too little room for real discussions. An abundance of (political) information is found online, but it does not necessarily lead to more informed internet users, nor does it automatically make for better or good 'netizens', digital citizens, cyber dissidents, or whatever term has been used to glorify the emergence of these new online political actors. And whereas Habermas's salons were most commonly places for the rich and, without exception, well-to-do middle-class males, greater participation in the internet era does not necessarily imply more diverse participants. As we have painfully learned, not all information is necessarily democratic, even though a new vibrant online community of 'produsers' and their user-generated content may leave such an impression on the surface, as Kermani attests in his contribution to this issue: in the hands of Iranian users, the potentially subversive Telegram app seems to affirm, rather than contest, hegemonic discourse. 
Digital activism comes with its own established history, some of it so accepted that it easily travels from one place to another. See, for example, Castell's (2015) linking of the Serbian civic Optor movement with the Egyptian 6 April movement and, then, to the Occupy movement. ${ }^{1}$ Much online activism looks vaguely familiar and similar from one context to another, and some evidence indicates that not only do certain revolts and revolutions serve as templates but that actors, tactics, and manuals in one place can easily go 'viral' and become teaching materials for activists elsewhere. Juris (2005: 191) points out that such interactions can lead to sustainable 'computer-supported social movements', arguing that 'using the Internet as technological architecture, such movements operate at local, regional, and global levels, while activists move back and forth between online and offline political activity'.

Indeed, this transnational dimension of activism, with its recurring tactics of cultural jamming, hacktivism, electronic disobedience, and on-the-spot organization, was on display during the various large-scale civil society movements that reverberated across East Asia in the 2010s. In particular in the Chinese-speaking world, the 2014 Sunflower movement in Taiwan and Umbrella movement in Hong Kong fruitfully played off each other's protest strategies and organizational protocols (for assessments, see Chen et al. 2015; Ho 2019; Jones 2017). ${ }^{2}$ Activists and civic hackers in the two movements maintained close ties throughout the tumultuous events, and they continued their collaboration in the aftermath. In 2019, when Hong Kong citizens again took to the streets in protest of their government, this time to challenge a controversial anti-extradition bill, these earlier collaborations powerfully informed a new wave of pro-democracy activism.

Somewhat arbitrarily, the roots of such movements are often traced to the Zapatista internet war of 1994, in which leftist activists in Mexico identified

1 Otpor ('Resistance') was a civic protest movement which, in the 199os, was formed by Serbian activists with the aim to oust dictator Slobodan Milosevic. Later Otpor leaders would teach nonviolent strategies and the subversive humour they were known for to others, including to some Egyptian activists of the 6 April Movement. This movement, founded in 2008, used blogs and social media platforms such as Facebook and Twitter to support workers that had gone on strike in the textile mills of Mahalla-al-Kubra (Castells 2015: 54).

2 The Sunflower movement was a social protest movement that was active throughout March and April 2014, and that used the Sunflower as its symbol; the movement consisted mostly of students and civic rights groups in Taiwan, who challenged the ruling Kuomintang (Кмт) on a controversial trade agreement that the party had tried to arrange with the People's Republic of China (PRC). The Umbrella movement was a protest movement that swept through Hong Kong from late September to mid-December that same year, and that challenged the plans of the PRC central government to pre-screen the candidates for Hong Kong's top government post. The popular name of the movement is derived from the practice of using umbrellas to shield protesters from pepper spray and water cannons. 
with the rural Maya, taking to the then-emerging World Wide Web to make their case. This eventually culminated in 1998 in the Floodnet attacks of the Electronic Disturbance Theatre, which not only 'disturbed' government web sites by overloading web servers through multiple simultaneous requests but also served as a manual for international hacktivism yet to come (Lane 2003: 132). This history also commonly includes references to the Battle of Seattle in 1999, when 40.000 activists took to the streets, micro-coordinating their protests against policies by the World Trade Organization using bottom-up and tactical media; their methods led to the emergence of the term 'smart mob' (Kahn \& Kellner 2004).

This history of online activism, more so than a conventional history of the internet (Goggin \& McLelland 2017), is fairly global, including accounts of People Power II in Manila in 2001 (Rafael 2003), where the revolution was texted, the Green Revolution in Iran in 2009, and, even more conspicuously, the much-covered Arab Spring in the Middle East and North Africa in 2011. The wealth of case studies has been accompanied by debates over whether these activities should be considered 'new social movements'. Proponents of this line of argument make the case that such movements constitute a fundamental rupture with the past; to formulate a new social movement theory, they point to the strong focus on identity politics (Fominaya 2010), the seemingly non-hierarchical networked organizational patterns (Pichardo 1997:416), the use of symbolic and theatrical activities (Cortes Vasquez 2010; Decreus et al. 2014; Lovink \& Rossiter 2015; Tarrow 2011: ch. 7), the creative re-appropriation of public space (Kaun 2015), and, of course, the ubiquitous use of digital technology for communication and organization (Carty 2013; Haunss 2015; Juris 2005; for an early overview of these discussions, see Beuchler 1995; for an update, see Foust \& Hoyt 2018).

Such new social movement theory has, however, been challenged by its critics for overplaying the supposedly post-materialist nature of such movements (see Eggert \& Giugni 2015; Peterson et al. 2015; Tucker 1991), which in fact often remain rooted in concerns over class and welfare issues, such as income disparity, housing costs, or health care, and which at times perpetuate long-standing geopolitical issues on territory and national sovereignty (see e.g. Kwan 2016). Importantly, accounts of 'micro' or 'networked' activism have often been criticized for highlighting merely progressive agendas and celebrating and prioritizing technology over what happens on the ground, thus turning a blind eye to the 'multidimensionality of society and non-Internet users' (Fuchs 2014). A long-standing debate has been going on among scholars, such as between Shirky (2008), who sees social media as cheap collective tools in the service of uncontrollable action that notably contribute to democracy, and Morozov (2013) and like-minded authors, who condemn social media for 
making existing hierarchies, surveillance, and other forms of oppression more efficient; these critics reject the utopian belief in 'technological fixes'. Whilst Morozov (2009) condemns digital activism as the ideal type of activism for a lazy generation', he and Shirky might both overstate the role of social technology in today's world of online engagement.

Criticizing some of the early (or maybe we should say: 'easy') accounts of such historic events, Postill (2014) advocates a more ethnographically informed approach to digital activism, asking us as scholars to focus on the peculiarities of each time and each cause, without overlooking possible connections and correspondences between such social agents. To that end, he studies 'freedom technologists', social agents who combine technological and political skills to pursue greater internet and democratic freedom. In his opinion, they are techno-pragmatists most of all, with a practical view of the limits and possibilities of technologies for social and political change. Postill also comes up with the idea of 'protest formulas', a combination of societal forces and outcomes that characterize each protest movement as well as each phase of such movements. In another context, looking at Indonesian online activism, Lim (2013) similarly explains why some forms of activism online fare better than others. Like Postill and Fuchs, she concludes that social media inherently do not promote civic engagement and that social media typically are not very well suited for deliberative discourse on complex issues. In Indonesia and elsewhere, they are also typically aimed at the urban middle class with its own preoccupations. Lim argues that digital activism works best when it begins with a simple narrative, using low-risk activism, and not straying too far from the dominant discourse.

More recently, Postill (2018: 1) has used the term 'techpol nerds' to refer to people 'who operate at the intersection of technology and politics, and who care deeply about the fate of democracy in the digital age'. Postil recounts that since 2010, pro-democracy digital freedom activism (both the pro-democracy and contrarian variants) has taken centre stage globally, from local forums and gatherings in Spain to Wikileaks and the Arab uprisings. They meet at the intersection of four sub-worlds or spaces - data activism, digital rights, social protests, and formal politics - and they engage in all sorts of 'part-nerdships'. To explain who these 'techpol nerds' are and what they want, he relies on three main strands in the literature, an overview that is very helpful for this special issue on digital activism: (1) the literature on the digitization of traditional politics and the politicization of the digital realm, (2) hacker ideals and ideas, such as the recursive public ('hackers arguing about technology but also arguing with and through it') by Kelty (2008) and Coleman's 'weapons of the 
geek' (2017), and (3) a more local Spanish-language strand of the literature on technopolitics.

\section{Asian Activisms}

What is missing from this literature that would help us understand today's forms of digital activism in Asia? Is it necessary to study digital activism from an Asian perspective? For example, does it require its own theorizing? These questions return us to earlier debates, for example, on the value of area studies in looking at the potential of the digital to cross borders (on this topic, in previous DIAS issues, see also Schneider 2015; Schneider \& Goto-Jones 2014). This special issue studies some Asian intricacies, inquiring when these intricacies occurred and what they are, whether some of the above-mentioned literature studies Asian politics, and whether today's Asian activism merits its own theoretical approach. Although not all contributions to this issue address the need for this novel theorizing equally, and some of them use terminology first invented for political conditions and debates elsewhere, some factors might require a revised perspective.

The first motivation to do so is that much of what has happened politically in Asia over the past few decades - which might not be entirely uniquedemonstrates ongoing ambiguity in the relationship between authoritarian regimes and their citizens, particularly between the state and the middle class. Because of continuous growth over the past 40 years in much of capitalist Asia (and beyond, as countries such as socialist Vietnam are hardly an exception), a new class has emerged that is beyond patronage, well educated, and both physically and socially very mobile. The rise of this middle class legitimizes authoritarian regimes armed with the latest statistics, and internet access and social media use have lately become among the most popular indicators of the state's economic success. Yet economic success also leads to social envy, class contradictions, and too much success, which has become a concern for Asian authorities, who fear a loss of control. Pinches (1999) argues that, the Asian middle class has served as both the backbone and the nemesis of some of Asia's worst regimes. From the Tiananmen protests in China in 1989 and Black May3 in Bangkok in 1992 to People Power II in the Philippines in 2001

3 'Black May' is the name used for the May 1992 protests in Bangkok against the then ruling military junta. The forceful suppression of the demonstrations would eventually leave over 5 o people dead, with hundreds injured or disappeared and many arrested. 
and Hong Kong's recent anti-extradition protests, the first revolutionary sparks have always been ignited by Asian middle-class activists, many of whom are young and students. The middle class might merit an analysis that is wholly different from that of its peers in the West, considering that members of the contentious Asian middle class are often obsessed with consumption rather than the means of production, as is the case in more conventional Marxist class analysis, and they use social media in surprising and subversive ways, even if this usage is not always recognisable as outright political. The contribution to this issue by Liew and Abidin illustrates this point very well.

In each of these middle-class struggles, both mass and local media filled a prominent role-from the 'televised revolts' on Tiananmen Square to Indonesia's Revolution of Small and Mobile Media in which the internet and laptops in 1998 were used by students to overthrow the regime of President Suharto (Hill and Sen 2005), to the 'mobile revolution' that embodied People Power II, to the highly 'memetic' activities among Hong Kong activists. We try not to overly celebrate either the role of the middle class or its telecommunication fantasies. As Rafael (2003) has pointed out in relation to the ousting of Filipino dictator Joseph Estrada during People Power II, these revolutions may be ignited by what seems to be a simple text message, they may be won in the street through the occupation of squares and main boulevards, and the victory may belong to young inspirational and charismatic leaders or, better yet, the crowd. Yet, in reality, these victories are carefully master-minded elsewhere, often jointly led by existing authorities (the Catholic Church in the case of People Power II, the Muslim Brotherhood in the case of the Arab uprisings), and they are supported by conventional, not-very-new media (the Church-owned Radio Veritas or the Friday sermon). They do best after receiving backup from traditional political players or resorting to more conventional political strategies (see also an account of Partido X in Catalunya in Postill [2018]).

This is by no means intended to downplay the potential power and subversion of local, strategic, and social media; rather, it calls for a more careful interrogation of precisely what happens on the ground. Excessive romanticism about urban social media activism may run a risk, which is also well illustrated by Rafael's (2003) People Power II example. When middle-class progressive idealists take to the streets, not only is the popular pro-democratic press in the West eager to cover it but so are social science and humanities scholars. Much less attention is usually reserved for the not-so-progressive, populist cause that might use platforms and social media tactics that are similar to those used by pro-democracy activists. This may even include the same kind of memes, 
short video e.g. on Vine, or flash mob aesthetics, and yet this activism is often absent from our accounts. One exception to that is emergent literature on popular religion online (see e.g. Bellar et al. 2015; Slama \& Barendregt 2018), as well as on digital nationalism (e.g. Schneider 2018: chaps. 6 and 7), some of which looks at reactionary activism in its most fundamentalist forms. Another exception are studies that explore how authoritarian regimes have used usergenerated content in pursuing their own agenda, as outlined in this issue by Anissa Beta and Nurul Azlan.

One final thing is worth keeping in mind about all five contributions to this issue. Using some of the tactics, templates, and the very 'feel' that the early activists popularized can at first make almost anything look as if it is political and truly engaging, but, on second glance, the use of recognizable tropes and practices raises many questions about the meaning of activism in the digital era. Much of what does not traditionally pass for politics or the political may ultimately become political, not just because of older activist arguments that the personal is political but precisely because social media today are so efficient at making everything private into something public, leading to further negotiation between the two. The most banal messages uploaded from one's own bedroom may soon attract a following and then create political momentum. In this issue, Seto offers an example in describing the emergence of an online community of namesakes-in this case, people who share the name Agus. After such an online community becomes popular and many Aguses join the 'brotherhood', what started as an online gimmick can easily become an inclusive community, membership in which is greatly sought, and this community can then become a movement with a significant impact of its own, thus serving as platform or vehicle for yet other needs and agendas. Paraphrasing Billig (1995), it then easily becomes a tool for 'banal politics'. This does not necessarily mean politics with a capital $\mathrm{P}$ but, rather, every-day forms of engagement, with sometimes seemingly vulgar contents and often familiar routines and local forms, yet the impact of this banal activism may have political implications.

The contributions to this issue partly follow a previous discussion in Asiascape: Digital Asia (DIAs 6.3), on Rethinking Communities in the Age of the Digital. Moreover, most of the articles are inspired by a similarly titled conference at Leiden University on 29 May 2018. This issue of DIAS covers several instances 
of digital activism, some more politically motivated than others, some touching upon and driven by more every-day and banal forms of engagement-not all of which are necessarily secular in character, nor can they always be characterized as liberal.

Anissa Beta's article is a good case in point. Responding to an earlier DIAS article by Nisa (2018), she claims that contemporary da'wa activism (proselytizing Islam) has greatly changed the public face of Indonesian Islam now that it is mediated through YouTube videos, tweets, or, in this case, highly designed Instagram posts. She writes that this has transformed $d a^{\prime} w a$ activists, many of whom are young Muslim women who are increasingly organized into social media communities in which they 'discuss, engage with, and express how they "feel" about issues they are interested in, and celebrate selfimprovement and self-enterprise combined with religious self-cultivation'. Beta also shows that the sense of intimacy that prevails in these online communities leads them to use a vocabulary and media aesthetics that cannot be too overtly political. This new-style $d a^{c} w a$ activism, then, is as much about religion and spirituality as it is about capitalism and consumption, and it should be studied, Beta concludes, as the products of a 'Muslimah intimate public' in which civic participation is continuously 'conditioned by neoliberal productivity'.

Also in Indonesia, Ario Seto offers a 'thick description' of three online communities: Kaksus, the largest online community in the country; Yogyakarta Fixed Gear, a hobby-forum-turned-community; and Agus-Agus Bersaudara Se-Indonesia, a community of members with a common first name, Agus. Although they emerged at different times, each is primarily geared towards leisure activities with social activism (and maybe even a 'sense of community') only afterwards and seemingly unintended. Following Putnam (2000), and the supposed relationship between community, civic engagement, and citizenship, Seto defines 'social activism from below'. In each of the three communities, 'community activism' may not be outspokenly political in character; nevertheless, members believe that their civic engagement is meaningful for society at large. Because they have a wide-ranging social media landscape at their disposal, offering a plethora of new features and platforms, initiating community and civic engagement is no longer complicated. The challenge is clearly in how to keep such a community alive and, as Seto illustrates, "keep it abreast of growing techno-social complexities'.

In her article, Nurul Azlan describes the use of hashtag politics in 2015, when Bersih 4 protesters took to the streets in three large Malaysian cities, as well as the counter-measures taken by government-employed cybertroopers, trolls, and producers of 'fake news'. In her analysis, Azlan combines the spatiality 
of digital activism and the participatory nature of hashtag activism, showing how place-based analysis (through metadata) proves unreliable, whereas participatory politics leave social media activism vulnerable and exposed to manipulation by political opponents. Discussing the popular hashtag \#Bersih4 and how it was used by activists, she discerns some patterns in postings that, through their use of place names in their tweets, obviously betray the presence of cybertroopers, thus making visible what should have remained unseen. In this way, Azlan's article is a fine example of a growing body of literature on counter-activism and the ways in which not-so-progressive forces using the same internet and social media tactics as their counterparts, but as a disruptive force to silence dissent.

In a somewhat similar vein, Hossein Kermani looks at Telegram and how Iranians used the app in the period preceding the 2017 presidential elections. His contribution illustrates that one cannot assume that social media (or the concept of the 'produser' he discusses) always and inevitably promote democratic debate or values. Even though the Telegram app seemingly remaining below the radar of Iranian authorities and had a preference for 'user-generated content', a sample of the most popular posts during that period shows that, by far, the majority originated from official channels linked to state institutions and actors. This 'popular content' mostly facilitates and endorses the hegemonic discourses in and of the authoritarian regime. Yet, in May 2018, Telegram was permanently banned in the country, so 40 million Iranians are now resorting to virtual private networks and proxies to enable continued use of the app. Future research has to yet prove whether more subversive content now appears on the now illegal platform.

The final article in this issue is by Kai Khiun Liew and Crystal Abidin on the si geena in Singapore. It discusses the online activities of juvenile resistance, which may not always or automatically be recognized as straightforward political or activist activities. The Hokkien term si geena has come to refer to young brats who episodically and often openly create public controversy. Their behaviour is intentionally in your face, meant to be subversive and indecent, and always outrageous, yet these si geena are 'neither activists nor delinquents'. Opting for an emic analysis and following this local concept and the local discourses in which it is embedded, the authors show that in offending public morality and exposing the state's fangs, the si geena of Singapore tested both the claims and the extent of society's openness to and tolerance of dissenting voices'.

All the articles in issue show the ultimate importance today of Asian politics with both banal and every-day or highly subversive digital forms of engagement and scholarly scrutiny of them. 


\section{References}

Bellar, Wendy, Campbell, Heidi, Cho, Kyong James, Terry, Andrea, Tsuria, Ruth, YadlinSegal, Aya, \& Ziemer, Jordan (2015), 'Reading Religion in Internet Memes'. Journal of Religion, Media and Digital Culture, 2(2), 1-39.

Beuchler, Steven (1995), 'New Social Movement Theories'. Sociological Quarterly, 36(3), 441-464.

Billig, Michael (1995), Banal Nationalism. Los Angeles: Sage.

Carty, Victoria (2013), 'Bridging Contentious and Electoral Politics: MoveOn and the Digital Revolution'. In Coy, Patrick G. (ed.), Research in Social Movements, Conflicts and Change. Bingley: Emerald Group, pp. 171-196.

Castells, Manuel (2015), Networks of Outrage and Hope: Social Movements in the Internet Age. Cambridge: Polity.

Chen, Hsuan-Ting, Ping, Sun, \& Chen, Gan (2015), 'Far from Reach but Near at Hand: The Role of Social Media for Cross-National Mobilization'. Computers in Human Behavior, 53, 443-451.

Coleman, Gabriella (2017), 'From Internet Farming to Weapons of the Geek'. Current Anthropology, 58(S15), S91-S102.

Cortes Vasquez, Judith (2010), 'New Social Movements and the Use of ICT: The Colombian Case of 4 February 2008'. International Journal of Media and Cultural Politics, 6(3), 351-358.

Decreus, Thomas, Lievens, Matthias, \& Braeckman, Antoon (2014), 'Building Collective Identities: How New Social Movements Try to Overcome Post-Politics'. Parallax, $20(2), 136-148$.

Eggert, Nina \& Giugni, Marco (2015), 'Does the Class Cleavage Still Matter? The Social Composition of Participants in Demonstrations Addressing Redistributive and Cultural Issues in Three Countries'. International Sociology, 3o(1), 21-38.

Fominaya, Cristina Maria Flesher (2010), 'Collective Identity in Social Movements: Central Concepts and Debates'. Sociology Compass, 4, 393-404.

Foust, Christina R. \& Hoyt, Kate Drazner (2018), 'Social Movement 2.o: Integrating and Assessing Scholarship on Social Media and Movement'. Review of Communication, 18(1), 37-55.

Fuchs, Christian (2014), 'Book Review: Manuel Castells, Networks of Outrage and Hope: Social Movements in the Internet Age'. Media, Culture \& Society, 36 (1), 122-124.

Gerbaudo, Paolo (2012), Tweets and the Streets. London: Pluto Press.

Goggin, Gerard \& McLelland, Mark (2017), 'Introduction: Global Coordinates of Internet Histories'. In: Goggin, Gerard, \& McLelland, Mark (eds.), The Routledge Companion to Global Internet Histories. London: Routledge, pp. 23-42.

Habermas, Jürgen (1991), The Structural Transformation of the Public Sphere: An Inquiry into a Category of Bourgeois Society. Cambridge, MA: MIT Press. 
Haunss, Sebastian (2015), 'Promise and Practice in Studies of Social Media and Movements'. In: Dencik, Lina \& Leistert, Oliver (eds.), Critical Perspectives on Social Media and Protest: Between Control and Emancipation. New York: Rowman \& Littlefield International, pp. 13-3o.

Hill, David T. \& Sen, Krishna (2005), The Internet in Indonesia's New Democracy. London: Routledge.

Ho, Ming-sho (2019), Challenging Beijing's Mandate of Heaven: Taiwan's Sunflower Movement and Hong Kong's Umbrella Movement. Philadelphia: Temple University Press.

Hopkins, Julian (2014), 'Cybertroopers and Tea Parties: Government Use of the Internet in Malaysia'. Asian Journal of Communication, 24(1), 5-24.

Hudson, Chris \& Barendregt, Bart (eds.) (2018), Globalization and Modernity in Asia: Performative Moments. Amsterdam: Amsterdam University Press.

Jones, Brian C. (ed.) (2017), Law and Politics of the Taiwan Sunflower and Hong Kong Umbrella Movements. Abingdon, UK: Routledge.

Juris, Jeffrey S. (2005), 'The New Digital Media and Activist Networking within AntiCorporate Globalization Movements'. Annals of the American Academy of Political and Social Science, 597(1), 189-208.

Kahn, Richard \& Kellner, Douglas (2004), 'New Media and Internet Activism: From the "Battle of Seattle" to Blogging'. New Media \& Society, 6(1), 87-95.

Kaun, Anne (2015), “'This Space Belongs to Us!" Protest Spaces in Times of Accelerating Capitalism'. In: Dencik, Lina \& Leistert, Oliver (eds.), Critical Perspectives on Social Media and Protest: Between Control and Emancipation. New York: Rowman \& Littlefield International, pp. 89-106.

Kelty, Christopher M. (2008), Two Bits: The Cultural Significance of Free Software. Durham: Duke University Press.

Kwan, Justin P. (2016), 'The Rise of Civic Nationalism: Shifting Identities in Hong Kong and Taiwan'. Contemporary Chinese Political Economy and Strategic Relations: An International Journal, 2(2), 941-973.

Lane, Jill (2003), 'Digital Zapatistas'. TDR/The Drama Review, 47(2), 129-144.

Lim, Merlyna (2013), 'Many Clicks but Little Sticks: Social Media Activism in Indonesia'. Journal of Contemporary Asia, 43(4), 636-657.

Lim, Merlyna (2018), 'Roots, Routes, and Routers: Communications and Media of Contemporary Social Movements'. Journalism \& Communication Monographs, $20(2), 92-136$.

Lovink, Geert \& Rossiter, Ned (2015), 'Network Cultures and the Architecture of Decision'. In: Dencik, Lina \& Leistert, Oliver (eds.), Critical Perspectives on Social Media and Protest: Between Control and Emancipation. New York: Rowman \& Littlefield International, pp. 219-232. 
Morozov, Evgeny (2009), 'The Brave New World of Slacktivism'. Foreign Policy, 19(5), retrieved 21 January 2020 from: https:/foreignpolicy.com/2009/05/19/the -brave-new-world-of-slacktivism/.

Morozov, Evgeny (2013), To Save Everything, Click Here: Technology, Solutionism, and the Urge to Fix Problems That Don't Exist. New York: Penguin Press (Kindle ed.).

Nagle, Angela (2017), Kill All Normies: Online Culture Wars from 4chan and Tumblr to Trump and the Alt-Right. Alresford, UK: John Hunt.

Nisa, Eva (2018), 'Creative and Lucrative Da'wa: The Visual Culture of Instagram amongst Female Muslim Youth in Indonesia'. Asiascape: Digital Asia, 5(1-2), 68-99.

Papacharissi, Zizi (2008), 'The Virtual Sphere 2.o: The Internet, the Public Sphere, and Beyond'. In: Chadwick, Andrew \& Howard, Philip N. (eds.), Routledge Handbook of Internet Politics. London: Routledge, pp. 246-261.

Peterson, Abby, Wahlström, Matthias, \& Wennerhag, Magnus (2015), 'European AntiAusterity Protests: Beyond “Old" and "New" Social Movements?' Acta Sociologica, 58(4), 293-310.

Pichardo, Nelson A. (1997), 'New Social Movements: A Critical Review'. Annual Review of Sociology, 23, 411-430.

Pinches, Michael (Ed.) (1999), Culture and Privilege in Capitalist Asia. London: Routledge.

Postill, John (2014), 'Freedom Technologists and the New Protest Movements: A Theory of Protest Formulas'. Convergence, 20(4), 402-418.

Postill, John (2018), The Rise of Nerd Politics. Digital Activism and Political Change. London: Pluto Press.

Putnam, Robert D. (2000), Bowling Alone: The Collapse and Revival of American Community. New York: Simon \& Schuster.

Rafael, Vicente (2003), 'The Cell Phone and the Crowd: Messianic Politics in the Contemporary Philippines'. Public Culture, 15(3), 399-425.

Schneider, Florian (2015), 'Searching for "Digital Asia" in Its Networks: Where the Spatial Turn Meets the Digital Turn'. Asiascape: Digital Asia, 2(1-2), 57-92.

Schneider, Florian (2018), China's Digital Nationalism. New York: Oxford University Press.

Schneider, Florian \& Goto-Jones, Chris (2014), 'Revisiting the Emancipatory Potential of Digital Media in Asia: Introduction to the Inaugural Issue of Asiascape: Digital Asia'. Asiascape: Digital Asia, 1(1-2), 3-13.

Shah, Nishant, Puthiya Purayil Sneha, \& Sumandro Chattapadhyay (2015), Digital Activism in Asia Reader. Lünenberg: Meson.

Shirky, Clay (2008), Here Comes Everybody: The Power of Organizing without Organizations. London: Penguin.

Slama, Martin \& Barendregt, Bart (2018), 'Introduction: Online Publics in Muslim Southeast Asia'. Asiascape: Digital Asia, 5(1-2), 3-31. 
Standage, Tom (1998), The Victorian Internet: The Remarkable Story of the Telegraph and the Nineteenth Century's Online Pioneers. London: Phoenix.

Tarrow, Sidney G. (2011), Power in Movement (3rd ed.). Cambridge: Cambridge University Press.

Tucker, Kenneth H. (1991), 'How New Are the New Social Movements?' Theory, Culture \& Society, 8(2), 75-98.

Zhang, Weiyu \& Lallana, Emmanuel C. (2013), 'Youth, ICTs, and Civic Engagement in Asia'. International Communication Gazette, 75(3), 249-252. 